\title{
Does Accounting Disclosure of Ordinary Free Float, Investment Held and Strategic Ownership Matters for Corporate Financial Policies and Performance?
}

\author{
Nevine Sobhy Abdel Megeid, PhD, CMA \\ Associate Accounting Professor - Head of the Accounting Department \\ College of Management and Technology \\ Arab Academy for Science, Technology and Maritime Transport \\ nevinesobhy2@hotmail.com
}

Mohamed Hassan Abd-EImageed, PhD

Assistant Accounting Professor

Faculty of Commerce - Ain Shams University

mailto:Dr.mohamedabdelmageed@commerce.asu.edu.eg

m_meguied@yahoo.com

\begin{abstract}
This empirical research is the first which examine the relationship of "ownership structure-performance-leverage-dividend". Thus this research aims to observe the link between these variables for the interest of shareholders, potential investors, and managers. The ownership structure of a firm is examined for its link with its performance, capital structure and other decision making.

In this research paper, the main aims are to identify and explore the accounting disclosure of three defined ownership structure, the public ordinary ownership (free float shares) (FF), the strategic (managerial) ownership (SS), and the investment held ownership ( $\mathrm{IH})$ and also seek to investigate and examine how the ownership structure of companies influence corporate financial performance (profitability and liquidity), leverage and dividend policy using earnings per share (EPS), total assets (TA) and industry type (IND) as control variables.

Data used in the analysis were collected from the annual financial statements. dimensions. In the reserach the time series data of different variables related to Ownership structure, firm's performance and dividend policy of the companies is used. Four multiple linear regression analysis are used to test the research hypotheses. The sample used examines the effect of three types of ownership structure of companies other than financial ones as independent variables on return on equity ratio, current ratio, debt/equity ratio, dividend yield ratio as dependent variables of 116 companies listed on the Egyptian Stock Exchange between 2012-2017.
\end{abstract}


According to regression analysis, the results showed that there is a significant positive relationship between ROE and the three types of ownership structure (FF, IH, SS) and also with the EPS and it is found that the relationship between liquidity measured using the current ratio and ownership structure (FF and SS) is positive and significant, while for investment held ownership found a significant negative relatinship.

The result reveals also that all ownership structures are negetavely correlated with high extent to the financial leverage measured using debt/equity.

Findings indicate also an insignificant positive relationship between dividend yields and FF and SS, while for IH found insignificant negative. EPS found to have a significant positive impact on ROE and dividend yields. TA representing the firm size have a significant negative impact on the liquidity of firms and significant positive impact on its financial leverage level.

The findings in this research are useful for investors to understand how the financial policies and performance of firms are affected by the level and type of managerial ownership; high level of managerial ownership decreases the tendency of firms to go for debt financing, while increase the dividends yield as the EPS is enhanced in such firms.

Keywords: - Accounting Disclosure - Ownership Structure - Financial Performance - Financial Leverage - Dividend Policy.

\section{Introduction}

Nowadays, Egypt as an emerging market has become the focus of many international corporations, personal and institutional investors due to the high rates of its economic growth. Egypt became a market based economy and is more dependent upon foreign investments, that's why accounting information tends to play a critical role in the economy, thus it is required to develop accounting measures and reports to satisfy the demand of this transition. Various stakeholders mainly rely, for making efficient economic decisions, on the annual financial reports prepared by management. Thus management, board members and executives should ensure transparency of company's information by increasing timely manner disclosures of information, apart from the ones required by the standards and the regulators to protect the minority shareholders interest and to other interested parties (Ifraz Khan, et al., 2013).

The Capital Market Authority enforces laws and regulations to ensure that the top management of listed companies full complies with the accounting requirements and financial reporting standards. The Capital Market Authority can present high quality financial reporting to improve transparency of corporate financial reporting and the increase role of transparent financial reporting and periodical disclosure in attracting both strategic and portfolio foreign investments.

The Egyptian Exchange (EGX) has always enhances the extent of corporate transparency by continuously conducting workshops to its listed companies to 
ensure that full disclosure and governance rules are well communicated and that companies comply the rules.

The Egyptian Exchange require all companies having securities listed on EGX Boards to disclose the following: Financial statements on a quarterly and annual basis, all Material events, corporate actions, any amendments in board members / management team/ any main data in the listing application, board / general assemblies meetings minutes, quarter changes in shareholding structures.

Ownership structure is the percentage of ownership claims held by managers (insiders) and investors (outsiders) (Vroom and Mccann, 2009). The two types of ownership structure are shareholder concentration and dispersed ownership. Shareholder concentration occurs when a single largest shareholder owns majority of the shares (block holder ownership) while many dispersed investors own the rest (managerial ownership, state ownership, legal person ownership and foreign listing/shares ownership) (Ifraz Khan, et al., 2013). According to the Central Depository Law, requires all companies must disclose detailed information on the beneficiary owners, which are obtained from the registered owners.

The companies as well as Misr Clearing, Settlement and Central Depository Company keep registries for shareholders and update them continuously; however these registries do not denote the ownership of the ultimate beneficiary. Companies must present these registries to their annual general assemblies. Shareholders have the right to review the minutes of the general assembly meeting, which include, as annexes, the names of all the registered owners and the number of shares owned by each of them. Such information must also be made available to the administrative bodies (the Investment Authority, the Associations of Capital Sector and the holding companies).

Recently, Capital Market Authority has started to demand that the most active companies disclose their ownership structure of 5 percent or more. The new Capital Market Law as well as the new registration rules aims to promote ownership structure disclosure.

Disclosure of ownership structure is critical as it shows the extent of risk diversification of shareholders and give information - as an indicator - about the existence of agency problems in the company' management (Muzammal et al, 2016).

Ownership structure determines the extent of monitoring and affects the level of voluntary corporate disclosure. Generally, twenty percent of shareholding is adequate percentage for effective power and control and a determinant for decision and policies making such as dividends' decisions.

When the managerial ownership increases, this may indicate there is a conflict of interest between the controlling managers and external investors.

When the outsider shareholders found that investment decisions are made for the interest to maximize the insiders' wealth, at the expense of them, outsiders will find it critical to supervise owner managers by requiring more level of corporate disclosures and transparency. 
The remainder of this research paper is organized as follows: Section 2 introduces the literature review, research objectives and questions, hypotheses development and relevant proposed model design. Sections 3 presents the theoretical frameworks covering the accounting disclosure of ownership structure and the relationship between ownership structure and agency theory, corporate financial performance, corporate financial leverage and dividend policy. Section 4 discusses research methodology and defines the variables. Section 5 reported statistical results and discussion. Finally, conclusions are offered in Section 6.

\section{Literature Review}

One of the most important factors that affect dividend policy is the ownership structures and control of companies as shareholders, according to the proportion of their shares ownership is different in their control and rights in management. Controlling shareholders who have more interest and influence can directly intervening the execution activities and policy making.

Dividend policy play a critical role in agency interest's conflicts among managers and shareholders as managers are more interest in retaining earnings and recourses for reinvestment and growth strategies instead of paying dividends because the firm growth will increase their control power on these resources. On the other side, owners prefer dividends payments. If earnings are not distributed to the owners as dividends, the manager's intentions towards the benefits of the management can be changed or they can invest in unprofitable investments (Masoyi Dadi Aliyu et al., 2016).

Hui and Khine (2017) investigate the impact of ownership structure on firm performance in 1178 non-financial Chinese companies. The panel model shows a positive relationship between institutional ownership and firm performance. Also, the tradable proportion of shares has negative impact on firm performance; while both state ownership and ownership concentration has no such impact on firm performance.

Hassan Balali, et al. (2015) examine the Pearson's correlation relationship between the free float percentage with the current debt ratio of 70 listed companies in Tehran Stock Exchange using Kolmogorov-Smirnov test. Findings indicate a significant positive relationship between the research variables.

Hue and Thao (2015) tested relationships between dividend payout ratio, firm performance (Price to Earnings (P/E) ratio and Return on Asset (ROA)) and ownership concentration by examining 34 Vietnamese construction listed companies. Findings indicate that ownership structure increases the dividend payout level and the later is positively correlated with both firm performances. Also, ownership concentration impacts negatively $\mathrm{P} / \mathrm{E}$ ratio and has no impacts on ROA.

Ali (2014) examined the relationship between ownership structure and corporate voluntary disclosure in Tunisia. Findings shows that the level of 
corporate voluntary disclosure is negatively significantly correlated with the family ownership and block holder ownership, while it is positively significantly correlated with the fraction of institutional investor ownership and company performance.

Thanatawee (2014) investigated the impact of ownership structure on dividend policy of Chinese companies listed on Stock Exchange and found that higher concentration ownership affect positively dividend payout ratio.

Xuanfeng Zhang and Fu Jia (2014) help investors in Hong Kong to know the determinants of dividend payout by examine the relationship between ownership structure and dividend yield. Findings suggest that ownership structure and profitability as a control variable greatly affect positively divided yield, while firm size affect it negatively. It is concluded also that leverage and market-to-book has no impact on dividend policy.

Thanatawee (2013) show that there is a significant negative relationship between the percentage of free float rate and dividend payout ratio.

Uyar et al. (2013) examined determinates that affect the corporate voluntary disclosure in Turkey. Results indicate that there is a relationship between the voluntary information disclosure level and corporate governance mechanisms like firm size, auditing, percentage of independent board directors and corporate/institutional ownership.

Suleyman Karaca and Ibrahim Eksi (2012) examined the impact of share of the largest shareholder as ownership structure on performance of manufacturing companies, listed on the Istanbul Stock Exchange. Result shows that there is no significant relationship between ownership structures and financial based performance measures.

Ullah et al. (2012) found the ownership structure affects the dividend payout policy while minimizing the agency cost. They found a negative relationship between dividend payout and managerial ownership, while, it is positive relationship with foreign and institutional share ownership.

Syed Zulfiqar et al. (2011) examined the effect of ownership structure on dividend payout of Pakistani listed firms on the stock exchange. Results show a positive association between ownership structures and dividend payout policy.

Seyed (2010) investigate the impact of ownership structure on dividend payout policy of Iranian listed firms. Finding shows a significant positive relationship between highly concentrated ownership mainly institutional ownership and dividend payout, while it is a negative one with individual ownership.

Kafash (2009) tested the impact of the ownership structure on company's financial performance of Tehran firms. Findings indicate that the percentage of shares owned by the 5 largest shareholders has a negative relationship with performance, which was in contrast with the institutional shareholders that have a positive impact on financial performance. Namazi and Kermani (2008) investigate the correlation between ownership structure and company financial performance of Tehran Stock Exchange. Findings indicate a significant positive association between ownership structure and financial performance. 
Cui and $\mathrm{Wu}$ (2007) shows that the stock expected returns are affected negatively by both the size of firm and the higher free float ratio (tradable public shares), as the later makes the market of stock more liquid thus it leads to lower return.

Omneya Abdelsalam et al. (2008) investigated the impact of characteristics of board of directors' and ownership structure, on dividend policy of Egyptian listed companies. Results indicates a significant positive relationship between institutional ownership and financial performance and dividend payout ratio as firms with a higher ROE and a higher institutional ownership distribute more dividends.

Kahn (2006) tested the relationship between ownership structure and dividend payout in UK quoted firms. Findings show that there is a negative link between ownership concentration and dividend payout as firms with individual and large block stockholding has lower dividends payout.

Holderness (2003) argues that corporate financial performance is a determinant of the ownership structure, not the opposite. The reason is that external shareholders usually choose to reward the internals for favorable past performance, so the offer them compensation in the form of stock options.

Gursoy and Aydogan (2002) examined the link between ownership structure and the accounting (ROA and ROE) and market (price-to-earnings ratio and stock returns) based performance of listed firms in Istanbul. Findings show that there is a positive link between ownership concentration and market based stock performance while it is negative with the accounting profit.

Demsetz and Villalonga (2001) concluded that there no meangiful relationship between ownership structure and corporate performance. Their finding is matched with the agency cost that is offsetted due to the dispersed ownership.

Ozer and Yamak's (2001) found that ownership structure is has a significant effect on ROA, ROE and asset turnover. Findings indicate that highly concentrated ownership companies affect firm performance. Market control may not have the expected effects on firms' performance. As the dispersed ownership structure cause the ROA and the ROE decrease significantly.

Yurtoglu (2000) examined the main determinants of ownership structure of the Turkish listed companies. It is found that families and highly concentrated are the dominant shareholders and it has a negative effect on performance resulting in lower ROA, market price to book value ratios and dividend payout.

Agrawal and Knoeber (1996) indicate that there is a significant positive correlation between financial performance and insider ownership, while the increasing percentage of outsiders on the board and financial performance are negatively correlated.

Hermalin and Weissbach (1991) found that a firm performs better with increases in management ownership as this can increase their work motivation to raise the firm stock value.

Morck, Shleifer and Vishny (1988) argue that managerial ownership affects positively shareholder stock value at low levels of ownership and vise versa at 
high levels. This support the view that management is risk taker at low levels of ownership and they attitude changed to risk averse when their ownership increased to levels where their wealth becomes affected.

Jensen and Meckling (1976) introduce the agency theory, or the theory of ownership structure. This theory dictates that self- control managers (agents) can make decisions and behaviors that are not consistent with shareholders (principals) value maximization. They state that ownership structure affects corporate performance, and not vise versa. Also, they concluded that dividend payout decrease free cash flow available to managers thus this restrain them from investing in the risky unprofitable projects.

\subsection{Research Objectives and Questions}

The main objective of this research is to identify and examine the relationship between ownership structure and firm financial performance, financial leverage and dividend policy.

In particular, this research aims to answer the following questions:

1. Does the ownership structure (including ordinary free float shares, investment held and strategic ownership) affect the financial performance in terms of profitability and have a significant and positive impact towards companies' return on equity ratio in Egyptian listed companies?

2. Does the ownership structure (including ordinary free float shares, investment held and strategic ownership) affect the financial performance in terms of liquidity and have a significant and positive impact towards companies' current ratio in Egyptian listed companies?

3. Does the ownership structure (including ordinary free float shares, investment held and strategic ownership) affect the financial leverage and have a significant and positive impact towards companies' debt/equity ratio in Egyptian listed companies?

4. Does the ownership structure (including ordinary free float shares, investment held and strategic ownership) affect the dividend policy of companies in the Egyptian stock market and have a significant and positive impact towards companies' dividend yield ratio?

\subsection{Research Proposed Model and Hypotheses}

Figure (1) presents the research proposed model and in light of the research objectives, the following hypotheses are tested:

Hypothesis 1: Ownership structure (ordinary free float shares, investment held and strategic ownership) has a positive impact on return on equity ratio.

Hypothesis 2: Ownership structure (ordinary free float shares, investment held and strategic ownership) has a positive impact on current ratio.

Hypothesis 3: Ownership structure (ordinary free float shares, investment held and strategic ownership) has a positive impact on debt/equity ratio.

Hypothesis 4: Ownership structure (ordinary free float shares, investment held and strategic ownership) has a positive impact on dividend yield ratio 
Figure (1) Research Proposed Model: Does Ownership Structure Affect the Financial Performance and Policies of Egyptian Listed Firms?

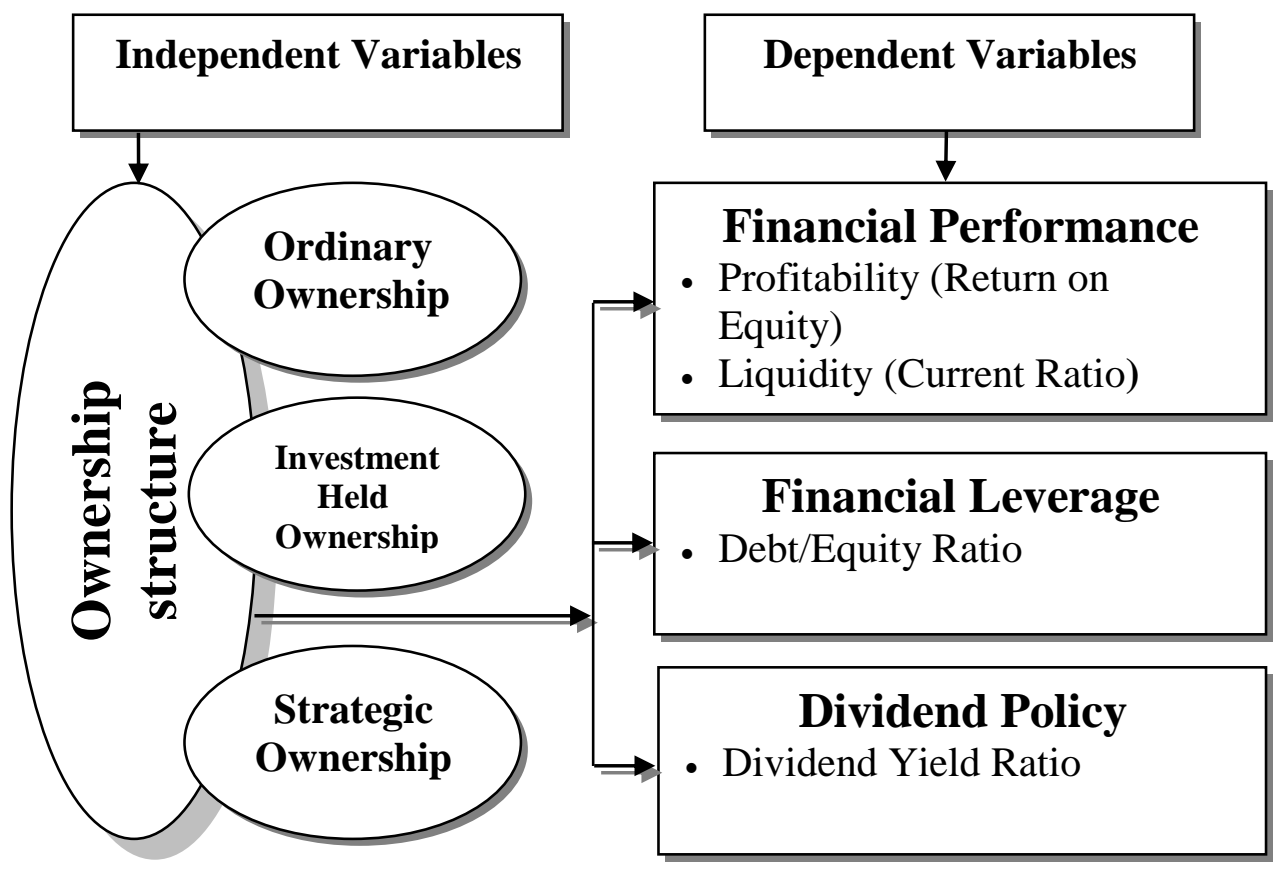

\section{Accounting Disclosure and Ownership Structure}

Disclosures of Accounting information has a critical roles in both developed and developing capital markets as it enables shareholders' and creditors' who provide company's capital to assess the potential return for their investment opportunities and also enables them to monitor the usage of their contributed capital by the company. Usually, agency problems (conflicts of interests) and information asymmetry affects the optimal allocation of resources in capital markets. Thus, Corporate accounting disclosure is one of the important mechanisms that facilitate safe information transmission between managers and investors, which helps in mitigating information asymmetry (Mahmoud, 2016) and it considered as an important tool for management to communicate company performance and governance to external shareholders.

It is noticed that the demand for high quality financial reporting and public Corporate disclosures to monitor manager performance appears to be less critical for companies with controlling managerial shareholders than for companies with dispersed ownership that heavily rely on outside managers (non-owners) to monitor management, in turn, this increases the potential for expropriation of minority shareholders (Hichem, 2007).

Disclosure enhances investor's confidence by improving the transparency of listed company.

It was argued that the shareholders' rights for information and to attend the shareholders' general meetings are restricted by the requirement of holding a minimum number of shares. This puts a constrain on their information rights 
as a minority shareholders and increases the problem of the influence of ownership structure on corporate information disclosure's It is observed that with high ownership concentration, controlling shareholders who hold significant cash flow rights are less reliant on minority shareholders and may have more incentives to expropriate benefits from minority shareholders or exploit private benefits as they do not support all the consequences of their decisions. Therefore, controlling shareholders may not have an incentive to disclose information to protect them (Chiraz, 2007).

Large institutional investors constrain management to disclose relevant information as they have more incentives and voting power that allows them to involved and undertake corrective actions when needed, because they possess significant financial investments and expect companies to meet their needs for information disclosure. Ajinkya et al. (2005) argue that large institutional investors demand more voluntary information disclosures especially about earnings forecasts.

On the other side, when the percentage of managerial ownership is greater, they have a strong voting power while the controlling power and monitoring capacity of outsiders is declined, and consequently results in less voluntary information disclosure by companies as they may have more incentive to reduce corporate transparency to preserve their own interests (Chau and Gray, 2010).

\subsection{Ownership Structure and Agency Theory}

Ownership structure is the composition of a company shareholding either by insider, outsider, institutional and government ownership, as well as others.

In Egypt, the main ownership structure involves controlling of some families, industrial and financial institutions, and the government. According to Egyptian regulations, disclosure of corporate ownership should in the updated shareholder list at the Annual General Meeting, but not in the annual report. The Egyptian Capital Market reinforces ownership the disclosure of ownership structure of 5 percent or more (Omneya Abdelsalam et al., 2008).

The nature of agency problem is depend on the ownership and control structure as it shows whether the conflict is between agents (managers) and principles (shareholders and other stakeholders), or between majority and minority shareholders.

Agency problems assumes theoretically that managers may have differences in their objectives, based on their interests and positions and will not always seek to maximize the shareholder value and fail to bear the full wealth effects of their decisions. The separation of ownership and control is critical as may managers (agents) of a publicly held firms use resources and conduct actions in a way that benefit them on the cost of shareholders' best interest (Zunaidah and Fauzias, 2008). 
Ownership structure in this research is divided into 3 different categories:

1. Ordinary Ownership (Free Float): the percentage of company shares that are publicly traded by investors in the stock exchange market as a percentage of total shares. It is the number of outstanding shares less the restricted shares from trading (stable shareholdings include shares that a parent company held for control of a subsidiary, cross-shareholdings among companies and shares held by the government).

2. Strategic Ownership (Managerial Ownership): the percentage of equity capital owned by managers, directors and those connected to them as a percentage of total shares.

3. Investment Held Ownership (Institutional Ownership): the percentage of equity capital owned by large financial institutions, such as insurance companies, mutual funds, pension funds and banks as a percentage of total shares.

The agency theory dictate that the corporate control is a critical external mechanism of corporate managements, thus if a company's managers pursue opportunistic, inappropriate strategies for a long period, the company will be undervalued in the market, and likely be targets for takeover, then this will enable subsequent management to make critical changes in strategy (King, 2011).

When shareholders are controlling and concentrated, they have powerful rights and greater incentives to monitor and influence management to maximize value and to protect their interest in the company. This increase the management accountability levels to provide full corporate voluntary disclosures to shareholders, it is expected that the level of voluntary disclosure will increase with the increase in shareholders ownership (Ifraz Khan et al., 2013).

In contrast, when the managerial ownership increase (measured by the percentage of ordinary shares held by the Executive Directors and CEO), this lead to reduce the agency cost and the managerial opportunism as the managerial ownership will decrease agency costs as the manager now owns a portion of the company's shares and will bear any managerial actions that either improve or destroy value of the company, therefore, one of the best ways to reduce the agency costs is to increase the shares hold by the managers. According to the agency theory, if earnings are not paid out to shareholders, they may be distributed to the insiders for personal use or invested in unprofitable investments that only provide private personal benefits to them. That's why, outside shareholders prefer earnings to be dividends over retaining them (Zunaidah and Fauzias, 2008).

Float is the percentage of free traded shares that is in the hands of investors and it excludes shares held by strategic owners like directors and managers of the company and by affiliated companies, shares held by government, shares held in employee share schemes, shares held by publicly-traded companies, shareholdings of 10 percent or more by private companies and individuals, and 
other blocks of shares that are considered to be strategically held or locked-in as opposed to freely tradable.

Free float ratio shows the company' ownership structure and can influence the stock prices in as, investors will avoid purchasing the stock if the free float ratio is low, which may cause liquidity problem in the market of that stock (Bostanc and Kilıç, 2010). The main concern is that investors in companies with a low free float ratio are at risk because it will mean they can exercise less control and monitor over the company.

\subsection{Ownership Structure and Corporate Financial Performance}

Ownership structure is concerned with both the equity distribution and the identity of the equity owners in terms of their control level and ability to make strategic decisions in an organization (Muzammal et al, 2016).

When managerial ownership increases, this increase their interests and managerial performance and make them exert significant effort to maximize shareholder value due to their ownership interests in corporate resources. Thus, the manager's claim on the outcomes of their performance and behavior increase with their equity percentage (Yabei and Shigemi, 2008). Therefore, balanced ownership structure can help companies to have a good performance in market (Hui and Khine, 2017).

The ownership can impact company performance in that concentrated ownership help in better controlling and monitoring of management, as both are positively correlated and this will improve company performance, voluntary disclosures and benefit minority shareholders (Jensen and Meckling, 1976). Profitability is one of the concerns of investors and main criteria in measuring the company financial performance. Managers of profitable companies tends to disclose more information thus, there is a positive correlation between better performing companies and corporate disclosure. Also, companies with greater liquidity are well performing companies as they have the ability to settle their short-term financial liabilities when came due without any significant loss and in the same time offer more liquidity in a way that managers can at least maintain dividend payout levels.

A company's free float ratio is critical to potential investors as it provides insight into the company's stock fluctuation. Increased liquidity is used to increase the percentage of free float share as when the free float share is high, in turn the company and the market potential liquidity will be high, with lower price volatility then reduced investment risk and this share is more preferable to the institutional investors. Free float share ratio can be used by managers to attract potential investors and increase the liquidity of their shares (Emad and Atefeh, 2013).

In contrast, the low free float ratio indicates less market shares that in the market, by means there is little equity and this reduces liquidity and in turn investors tend to avoid purchasing that limited share as it can be traded only in the event of major trading news. So, the relationship between the free float 
percentage and financial performance can assist in decision making and assessing the financial position of companies.

\subsection{Ownership Structure and Corporate Financial Leverage}

Agency costs and financial risk is affected by ownership structure and impact financing decisions. Capital structure decision measured using total debt to total equity ratio is influenced by company characteristics and by managerial ownership structure. By means, increase in financial leverage assist non owner managers to resist takeovers and reinforce their control, they depend on high debt to signal a covenant to sell assets, thereby avoiding any attempts for takeover from external investors. On the other side, they are trading with equity for their own interests, if they invest the borrowed money in profitable projects and make a return that exceeds the interest paid on the borrowed funds.

Companies that have high managerial ownership usually depend less on debt and vice-versa, as high leveraged companies limits managerial discretion over the use of free cash flow and lowers the payout ratios. The reason is that in order to pay the fixed financial charge, companies need to retain their internal cash flow rather than distributing dividends to shareholders as paying dividends will be considered a quasi fixed cost that must be reduced to avoid adding extra cost of external financing.

Companies with high leverage tends to disclose more information that satisfy long-term creditors needs to assess their own credit risk and reduce lenders suspicions concerning the possibility of using their money to create wealth to shareholders and managers.

Lenders and creditors of the company are much interested in the amount of dividend paid. When the dividend paid is high, this indicate that less would be the amount available for paying interest (debt servicing) and face value debt redemption (Amitava, 2015).

On the other side, highly leveraged companies may pay higher dividends to its shareholders, aligned with the risk that they faced compared to other companies with lower financial leverage.

\subsection{Ownership Structure and Dividend Policy}

Dividend policy is a financial decision by the board of directors and can be either managed or residual. Residual dividend is the cash dividend remained after the company makes its investments evaluated using the net present value method. Managed dividend policy, the amount of divided decided to be distributed by managers to their investors and expected to affect positively share valuation. Dividend policy is set by managers who pursue in deciding the amount and frequency of dividend distribution to present shareholders to maximize their wealth. Shareholders' wealth is represented by the market price of the firm's equity shares. To achieve this goal companies distribute dividends. Dividends impact share market price as this provides a signals, about the company's profitability (Amitava, 2015). 
Dividend policy is affected by the ownership structure. It performs an important role in mitigating the conflicting interests between managers and owners about whether to pay dividend or to reinvest earnings (Xuanfeng and $\mathrm{Fu}, 2014)$. Majority stockholder ownership structure has a significant power and control impact on corporate key policies and decisions, like dividends' payout which play a role in controlling agency problems, by facilitating monitoring of capital market activities and performance (Omneya Abdelsalam et al., 2008).

Managers as agents might have incentives to achieve short-term profits to maximize their own wealth, whereas the owners as principles may prefer sustainable long-term firm growth. Dividends payments made to the shareholders for their funds contribution and as a compensation for business risk. Dividends payout is used as an indicator for the company financial wellbeing performance, future prospects and shareholder value and it helps investors to assess a company as an investment prospect and to predict the how much dividend yield. Large shareholders have more power and control over the board and can monitor, shape the dividend policy and expropriate company resources for their own private consumption in a way that can limit dividend payout. Generally, dividend payout decreases as the voting power of owner manager's increase, and it can be zero when they have absolute control; in contrast, it is always positive when institutional shareholders controlled the company (Masoyi Dadi Aliyu, et al., 2016).

High manager ownership may help in elimination of free cash flow problem and thus results in high dividend payout ratio (Syed Zulfiqar et al., 2011). Dividend payout may reduce free cash flow available that managers may either use personally or to invest in unprofitable projects. On the other side, when minority shareholders are secured by a higher legal protection, companies pay them higher dividends, compared to others where legal protection is weak (Zunaidah and Fauzias, 2008). Dividend payment is important for both investors and management as an indicator of company performance. The investor earnings per share represent a regular income and return for their investment and at the same time opportunity cost because it forgone the opportunities for them to invest in other profitable projects. On the other side, managers have to decide about the timing and amount of dividends distribution without damaging company's smooth profitable position as more dividends payment means fewer funds available for business investments (Muzammal et al, 2016).

According to the agency theory, outside shareholders usually prefer dividends distribution over retaining earnings. While, when managers are owners in the company, there usually be alignment of interest, and their opportunistic behavior is greatly reduced. As a result, managers are motivated and have incentive to enhance and maximize their wealth and company value, as they will be benefited from these improvements. Thus, higher levels of managerial ownership are correlated with better value of the company in the capital market (Zunaidah and Fauzias, 2008). 


\section{Research Methodology}

The sample used in this research consists of 116 Egyptian Stock Exchange listed companies. The secondary financial data used in this research was obtained from the audited annual financial statements for the period 2012 2017.

The sample composed of 116 companies as follows: 6 basic resources companies, 7 chemicals companies, 18 construction and materials companies, 13 financial services excluding banks, 19 food and beverages companies, 8 healthcare and pharmaceuticals companies, 8 industrial goods and services and automobiles companies, 1 company oil and gas company, 7 personal and household products companies, 12 real estate companies, 2 retail companies, 1 media company, 2 technology companies, 4 telecommunications companies, 7 travel and leisure companies, and 1 utilities company.

Typically data set has a cross sectional observations among different companies and re-sampled at a certain period of time, so a Panel data regression will be most applicable to represent such a linear relationship.

Ownership structure can be affect four factors namely, firm profitability, firm liquidity, financial leverage, and dividend policy.

The basic model is given below:

Ownership Structure $=f($ Profitability, Liquidity, Leverage, Dividend Yield $)$

In order to test the impact of ownership structure that have on these previous four factors, we will run the following four multiple regression models. Table (1) Summarizes, all research variables, their definitions and the calculations.

We consider the four multiple linear regression equations described as follows:

Hypothesis 1:

$$
R O E_{i t}=\alpha_{0}+b_{1} F F_{i t}+b_{2} I H_{i t}+b_{3} S S_{i t}+b_{4} E P S_{i t}+b_{5} I N D_{i t}+e_{i t}
$$

Hypothesis 2:

$$
C R_{i t}=\alpha_{0}+b_{1} F F_{i t}+b_{2} I H_{i t}+b_{3} S S_{i t}+b_{4} T A_{i t}+b_{5} I N D_{i t}+e_{i t}
$$

Hypothesis 3:

$$
D E_{i t}=a_{0}+b_{1} F F_{i t}+b_{2} I H_{i t}+b_{3} S S_{i t}+b_{4} T A_{i t}+b_{5} \mathrm{IND}_{\mathrm{it}}+e_{i t}
$$

Hypothesis 4:

$$
D Y_{i t}=\alpha_{0}+b_{1} F F_{i t}+b_{2} I H_{i t}+b_{3} S S_{i t}+b_{4} E P S_{i t}+b_{5} \mathrm{IND}_{\mathrm{it}}+e_{i t}
$$

Where:

$\alpha=$ the estimated regression constant term.

$\boldsymbol{b}_{1}, \boldsymbol{b}_{2}, \boldsymbol{b}_{3}, \boldsymbol{b}_{4}$ and $\boldsymbol{b}_{5}=$ the estimated regression independent parameter coefficients respectively. 


\section{Dependent variables used in the four regression models are as follows:}

- Profitability is measured by the return on equity ratio (ROE).

- Liquidity is measured by the current ratio (CR).

- Financial leverage is measured by the debt/equity ratio (D/E).

- Dividend policy is measured by the dividend yield ratio (DY).

Independent variables: Ownership Structure (OS) is classified as follows:

- Percentage of free float ordinary shares owned by the public shareholder (FF): The percentages of total shares available to ordinary investors. That means total number of shares less the strategic holdings. In general, only holdings of $5 \%$ or more are counted as strategic ownership.

- Percentage of investment held shareholders (IH): The percentage of total shares in issue as by investment banks or institutions. In general, only holdings of 5\% or more are counted as strategic ownership.

- Percentage of strategic shareholders (SS): The percentage of strategic share holdings of $5 \%$ or more.

Control variable: Three control variables used as follows:

- Earnings per Share (EPS) that measures the profitability.

- Total assets (TA) that measures size of the firm.

- Industry type (IND).

It $=$ Firm $\mathrm{i}$ in period $\mathrm{t}$. The subscript $\mathrm{i}$ indicate the cross-sections considered in the reserach and $t$ represents the time series behavior of the variables.

The choice of fixed effect model and random effect model depends on the results of $f$ test as well as Hausman test.

$\varepsilon=$ Standard error term.

Table (1) Research Variables, their Definition and the Calculations

\begin{tabular}{|c|c|c|c|}
\hline Variable & Proxy & Measured by & Definition and Calculation \\
\hline \multirow[t]{4}{*}{$\begin{array}{l}\text { Dependent } \\
\text { Variables }\end{array}$} & Profitability & $\begin{array}{l}\text { Return on } \\
\text { Equity Ratio } \\
\text { (ROE) }\end{array}$ & $\begin{array}{l}\text { Return on equity ratio }=\text { Net profit less } \\
\text { preferred dividend requirement divided by } \\
\text { average of last year's and current year's } \\
\text { common equity. }\end{array}$ \\
\hline & Liquidity & $\begin{array}{l}\text { Current Ratio } \\
\text { (CR) }\end{array}$ & $\begin{array}{l}\text { Current ratio }=\text { Total current assets divided } \\
\text { by total current liabilities. }\end{array}$ \\
\hline & $\begin{array}{l}\text { Financial } \\
\text { Leverage }\end{array}$ & $\begin{array}{l}\text { Debt/Equity } \\
\text { Ratio } \\
\text { (D/E) }\end{array}$ & $\begin{array}{l}\text { Debt/Equity Ratio = Total long and short } \\
\text { term debt divided by common equity. }\end{array}$ \\
\hline & $\begin{array}{l}\text { Dividend } \\
\text { Policy }\end{array}$ & $\begin{array}{l}\text { Dividend Yield } \\
\text { Ratio (DY) }\end{array}$ & $\begin{array}{l}\text { It expresses the dividend per share as a } \\
\text { percentage of the share price. Dividend } \\
\text { yield ratio = Cash dividends paid per share } \\
\text { divided by market price per share. }\end{array}$ \\
\hline $\begin{array}{l}\text { Independent } \\
\text { Variables }\end{array}$ & $\begin{array}{l}\text { Ownership } \\
\text { Structure } \\
\text { (OS): } \\
\text { Is measured by } \\
\text { three variables: }\end{array}$ & $\begin{array}{l}\text { Free Float } \\
\text { Ordinary Shares } \\
\text { (FF) }\end{array}$ & $\begin{array}{l}\text { Free float ratio of a company's publicly } \\
\text { traded shares. It is a measure of how many } \\
\text { shares are reasonably liquid. It is the } \\
\text { percentage of total nominal value of } \\
\text { publicly traded shares to the total nominal } \\
\text { value of all shares }\end{array}$ \\
\hline
\end{tabular}




\begin{tabular}{|c|c|c|c|}
\hline & \multirow{2}{*}{$\begin{array}{l}\text { - Free float } \\
\text { ratio. } \\
\text { - Institutional } \\
\text { Ownership } \\
\text { ratio. } \\
\text { - Managerial } \\
\text { Ownership } \\
\text { ratio. }\end{array}$} & $\begin{array}{l}\text { Investment Held } \\
\text { Shareholders } \\
\text { (IH) }\end{array}$ & $\begin{array}{l}\text { Institutional ownership is shares owned by } \\
\text { legal entities without any physical persons } \\
\text { involved in the process. This includes hedge } \\
\text { funds, investment funds and pension funds } \\
\text { etc. }\end{array}$ \\
\hline & & $\begin{array}{l}\text { Strategic } \\
\text { Shareholders } \\
\text { (SS) }\end{array}$ & $\begin{array}{l}\text { Strategic (managerial) ownership is shares } \\
\text { controlled by insiders (senior managers, } \\
\text { supervisors, and directors). It is the } \\
\text { percentage of shares held by board of } \\
\text { directors to the total numbers of shares } \\
\text { issued. }\end{array}$ \\
\hline \multirow[t]{3}{*}{$\begin{array}{c}\text { Control } \\
\text { Variables }\end{array}$} & Profitability & $\begin{array}{l}\text { Earnings Per } \\
\text { Share } \\
\text { (EPS) }\end{array}$ & $\begin{array}{l}\text { Earnings per Share }=\text { Net profit after tax } \\
\text { available to common stock divided by the } \\
\text { average number ordinary shares } \\
\text { outstanding. }\end{array}$ \\
\hline & Firm Size & $\begin{array}{l}\text { Total Assets } \\
\text { (TA) }\end{array}$ & $\begin{array}{l}\text { Total assets represents the sum of total } \\
\text { current assets, long-term receivables, } \\
\text { investment in unconsolidated subsidiaries, } \\
\text { other investments, net property plant and } \\
\text { equipment and other assets. } \\
\text { The size of the company is determined as } \\
\text { the natural logarithm of the total assets at } \\
\text { year-end. }\end{array}$ \\
\hline & Industry Type & IND & $\begin{array}{l}\text { Industry dummies representing industry } \mathrm{j} \\
\text { where } \mathrm{j}=1,2,3, \ldots, 16 \text {. } \\
\text { IND } 1=\text { basic resources companies, IND } 2 \\
=\text { chemicals companies, IND } 3= \\
\text { construction and materials companies, IND } \\
4=\text { financial services excluding banks, IND } \\
5=\text { food and beverages companies, IND } 6= \\
\text { healthcare and pharmaceuticals companies, } \\
\text { IND } 7=\text { industrial goods and services and } \\
\text { automobiles companies, IND } 8=\text { oil and } \\
\text { gas companies, IND } 9=\text { personal and } \\
\text { household products companies, IND } 10= \\
\text { real estate companies, IND } 11=\text { retail } \\
\text { companies, IND } 12=\text { media companies, } \\
\text { IND } 13=\text { technology companies, IND } 14= \\
\text { telecommunications companies, IND } 15= \\
\text { travel and leisure companies, IND } 16= \\
\text { utilities companies. }\end{array}$ \\
\hline
\end{tabular}

\subsection{Profitability}

Profitability of a company indicates the management ability in achieving target operating and helps investors to judge management effectiveness, measured through dividends distributed from current earnings. This independent variable was measures in this research through Return on Equity (ROE), which reflects management effectiveness to achieve profits. 
Profitability as an accounting performance measure may be correlated with the firm growth opportunities, and it is expected that companies with higher earnings have higher dividends payouts ratio as highly profitable big companies with more stable earnings has excess free cash flows (Eric and Daniel, 2002). Profitability is affected by ownership structure as for ex., if managerial ownership is increased, their interests will be matched with this of shareholders leading to possible reduction of conflicts and agency problem between the two parties and as a result, managerial ownership may lead to improvement of company' financial performance.

\subsection{Liquidity}

Liquidity is an indicator for financial market efficiency and growth. Continuous stock market trading with available buyers and sellers provide an increase in liquidity to the shareholders by providing them ready market with decrease in trading costs, as the number of transactions per unit time increases. When more shares are in the hands of the public (free float), this may lead to enhanced liquidity and volatility due to increasing the frequency of stock trading, while concentrated ownership leads to less liquidity and hence the benefits of market monitoring will accrue to all shareholders and increased company performance. Consequently, when the share has high liquidity, it will be more attractive to investors and may increase the share price.

There is an obvious relationship between ownership structure and information asymmetry as for ex., managers have better information, and a market maker's trading strategy for a stock with high managerial ownership will differ from the one with low managerial ownership (Maryam and Kolthoum, 2013).

\subsection{Financial Leverage}

The theory of capital structure theory dictates that financing through debt is preferable as it delivers tax savings to the company. Thus, when the level of debts increases this will cause an increase to the value of the company.

The debt pressure which is possibly affected by the ownership structure and performance through the monitoring function of debt holders by shareholders, financial leverage is measured as the ratio of the debt-to- capital employed.

Also, financial leverage expected to have a negative impact on dividend payout by reducing the need to pay out dividends and finally, financial leverage can positively assist in monitoring managers' behavior. Financial leverage may influence the company investment decisions and the discretion afforded its managers (Eric and Daniel, 2002).

\subsection{Dividend Policy}

Investors often use the dividend yield as an indicator of investment risk as they need to collect and evaluate information concerning to their investments decisions, since the dividend yield calculation is based on the share market price, it is considered as a relevant variable to test in the model which examine 
whether certain ownership structures affect the dividend yield to assist investors when developing their investment strategies based on key performance indicators.

The ownership structure of a company is often a function of company size, growth rate and correlated with its financial performance, capital structure and other decision making and is prone to the creation of agency costs and conflicts of different interests of stakeholders. Dividend ratio can assist in decreasing the agency cost and it can also give evidence to the investors about the company's estimation. The dividend ratio can be affected by the company ownership structures, for ex., Institutional investors may have an effective role at monitoring management than the individual investors due to the size of their investment.

Generally, concentrated ownership (block holders) where large shareholders own the large amount of a company stocks, plays a central role in corporate financial policies like dividend payment policy due to their monitoring of the management decisions to protect their significant investments. On the other side, the management itself usually gives large shareholders preference because of their voting that has an influential impact on company's critical decisions (Hamid Ullah et al., 2012).

\subsection{Ownership Structure}

Ownership structure categorized in this research as the percentage of shares held by public (free float ownership), institutions (institutional ownership) and managers (managerial ownership).

Ownership structure of each company is calculated based on the information existing in combination of shareholders in the last annual meeting. And during the year, ownership structure changes are modified with any updated information.

Free float the ratio of a company's outstanding shares, which is currently traded $\mathrm{n}$ the foreign exchange market so that investors to the public without any restriction or limitation in the stock market, to the total shares of the company excluding the outstanding shares held by strategic stakeholders, government or institutional investors who are least likely to sell their shares frequently in the market. In other words, free float share represent the number of shares that is expected to be traded in the short-term in current prices for potential buyers (Mahmoud and Abolfazl, 2014) after the deducting nontradable shares from the total capital of the company (Emad and Atefeh, 2013).

If the free float share of a company is very low (ownership is highly concentrated), means that the market shares is very little, this increase the opportunity to manipulate price by large traders and can lead to formation of price bubble and loss of market which consequently leads to reduced investors' confidence on the stock market. Here, investors will avoid demand trading on this shares because of the smaller number of shares that is floating in the market reduce the liquidity of the stocks and investors dislike the lack of 
liquidity and because high ownership concentration increases the probability of expropriation under the weak corporate governance structure by controlling owners (Faruk and Saim, 1997).

On the other side, if floating shares of a company is very high than the critical expansion of its market, the stock market of this share will be potentially more cash and its price volatility and investment risk will be lower as investors when making their investment decision take their consideration the correlation between the free float ratio and shareholder wealth.

When the ownership structure is less concentrated, this indicates that the management is separated from ownership and increases the conflict of interest between these two parties, but it is more likely that these companies are operated by better management (Zeynep, 2003).

Intuitional ownership are investors (outside ownership) such as pension funds, insurance companies, banks buying and holding a share of another bank or company among others.

The institution or individual that buy the company shares not only for the investment or to raise fund of the issuing firm, but also referring to the true ownership of the company as they will have an ownership title in the company issuing the shares (Aghion and Tirole, 1997). Due to their size of investments, institutional owners considered to have more control over the management and greater influence on the dividend determination compared to the individual investors.

The strategic ownership (insider ownership) represents the owners of the company who ate involved in and controlled the operational management. Today, many companies are managed by the majority shareholders. Strategic shareholders include government companies and agencies, treasury stock, shares of managers and board of directors and family members and shares of workers.

Either an extreme high or low managerial ownership percentage is not preferred. As when strategic ownership is very high, this will lead to lesser holdings by retail and institutional investors. Consequently, strategic owners may make decisions that are adversarial to retail and institutional shareholders interest. On the other side, when strategic ownership is very low this may indicate that promoters are not much willing to invest in the company and are not interested in running the company. Managerial ownership is often given as incentives to dissuade management from pursuing personal interest at the detriment of corporate interest.

The company's control structure affects the dividend policy and that concentrated and leading shareholders in a control structure may generate private benefits that they do not prefer to share these benefits with the minority shareholders. There are different shareholder types, but the institutional shareholders and the managerial shareholders have a greater control over the company's policies as compared to other types (Muzammal et al., 2016). 


\subsection{Control Variables}

Earnings per share (EPS) is used as a control variable to measure the company's profitability. When the EPS is high, this indicates a higher possibility that the company is generating sufficient cash from operation and most likely to distribute dividends to shareholders.

Also, the company size is used as a control variable because large companies implies that it is in a mature stage with better growth opportunities and most likely to have stable cash flows generation both internally and externally and surplus financial assets to payout cash dividends to the shareholders compared to smaller companies. Generally, large companies have higher agency problem as they usually have large boards managed by the professional managers. Thus, it needs to pay more dividends to decrease the agency costs. Company size is measured as the natural logarithm of total assets (Zeynep, 2003).

Finally, the industry type is one of this research control variables. Dividend policy decisions are affected by the differences between industries. According to Anil and Kapoor (2008), the funds required for labor recruitment and retention are relatively less in a service industry that is more dependable on manpower, while in manufacturing industry, to operate huge capital investments are required. Therefore, service companies may have high liquidity than manufacturing companies. Consequently, it is claimed that it can easily pay high dividends due to its high liquidity.

\section{Statistical Results and Discussion}

This section presents the descriptive statistics, statistical tests empirical results and findings in order to evaluate the research hypotheses. Tests for normality, linearity, heteroscedasticity are conducted in order to test whether the assumptions of the regression models are fulfilled.

The data gathered from the annual audited financial statements of 116 nonfinancial listed companies at Egyptian Stock Exchange covering 16 different industries from the period 2012-2017.

\subsection{Descriptive Statistics Analysis}

Table (2) presents the descriptive measures to all variables of research. The table reports the mean, standard deviation, minimum, maximum, and the number of observations for each of the dependent and independent variables. The description statistic shows that, first, the mean value of ROE is 12.239 , and debt/equity is 41.56 , dividend yield 4.925 and for current ratio is 2.1682 . These indicators show that listed companies do not operate really efficiently during the study period 
Table (2) Descriptive Summary for all Research Variables

\begin{tabular}{|c|c|c|c|c|c|c|c|c|c|c|}
\hline & ROE & FF & IH & SS & TA & EPS & IND & D_E & DY & CR \\
\hline Mean & -12.239 & 38.777 & 0.6801 & 61.136 & 44.3044 & 2.4211 & 6.2589 & 41.565 & 4.9258 & 2.1682 \\
\hline Median & 9.7300 & 37.000 & 0.0000 & 63.00000 & 972582 & 0.5100 & 5.0000 & 13.120 & 3.6800 & 1.3500 \\
\hline Maximum & 62.720 & 100.00 & 31.000 & 100.00 & 681937 & 72.230 & 16.000 & 1998.1 & 53.730 & 61.860 \\
\hline Minimum & -2235.8 & 0.0000 & 0.0000 & 0.0000 & 25200 & 0.0000 & 1.0000 & -1145.9 & 0.0000 & 0.0000 \\
\hline Std. Dev. & 209.07 & 23.107 & 3.5526 & 23.190 & 100124 & 5.8599 & 3.8476 & 137.25 & 5.6916 & 3.9604 \\
\hline Skewness & -9.9393 & 0.6500 & 6.0909 & -0.6551 & 3.9259 & 6.5226 & 0.8388 & 3.1887 & 2.0875 & 9.9916 \\
\hline Kurtosis & 101.68 & 3.0890 & 42.277 & 3.1010 & 19.294 & 61.748 & 2.8328 & 86.119 & 13.525 & 129.28 \\
\hline Jarque-Bera & 270649 & 45.351 & 45167 & 46.129 & 8737.8 & 96726 & 75.919 & 185609 & 3424.6 & 436579 \\
\hline Probability & 0.0000 & 0.0000 & 0.0000 & 0.0000 & 0.0000 & 0.0000 & 0.0000 & 0.0000 & 0.0000 & 0.0000 \\
\hline Sum & -7845.5 & 24856. & 436.00 & 39188 & 2.84 & 1551.9 & 4012.0 & 26643. & 3157.4 & 1389.8 \\
\hline Sum Sq. Dev. & 279760 & 341721 & 8077.4 & 344192 & 6.42 & 21976 & 9475.0 & 120577 & 20732 & 10038 \\
\hline
\end{tabular}

\subsection{Correlation Matrix}

Pearson's correlation matrix (tables $3,4,5,6$ ) shows that the degree of correlation between the independent variables is either low or moderate, which suggests the absence of multicollinearity between independent variables used in the four linear regression models used to test the four research hypotheses as follows:

For the linear regression model (1) which used to test the first hypothesis,

$$
R O E_{i t}=\alpha_{0}+b_{1} F F_{i t}+b_{2} I H_{i t}+b_{3} S S_{i t}+b_{4} E P S_{i t}+b_{5} I N D_{i t}+e_{i t}
$$

Table (3) estimating the relation between (ROE), (FF), (IH) and (SS), it's found that there is a direct weak correlation between ROE, FF, IH and EPS while there is an inverse weak correlation between ROE, SS and IND.

Table (3) Correlation Matrix between First Hypothesis Variables

\begin{tabular}{|c|c|c|c|c|c|c|}
\hline & ROE & FF & IH & SS & EPS & IND \\
\hline ROE & 1.000000 & & & & & \\
\hline FF & 0.043655 & 1.000000 & & & & \\
\hline IH & 0.024895 & 0.041019 & 1.000000 & & & \\
\hline SS & -0.043404 & -0.997764 & -0.040162 & 1.000000 & & \\
\hline EPS & 0.064276 & -0.181669 & -0.018895 & 0.182523 & 1.000000 & \\
\hline IND & -0.126230 & 0.006855 & -0.054400 & -0.005810 & -0.123834 & 1.000000 \\
\hline
\end{tabular}

For the linear regression model (2) which used to test the second hypothesis,

$$
C R_{i t}=a_{0}+b_{1} F F_{i t}+b_{2} I H_{i t}+b_{3} S S_{i t}+b_{4} T A_{i t}+b_{5} I N D_{i t}+e_{i t}
$$

Table (4) estimating the relation between (CR), (FF), (IH), and (SS), it's found that there is a direct weak correlation between CR and FF while there is an inverse weak correlation between CR, IH, SS, TA and IND. 
Table (4) Correlation Matrix between Second Hypothesis Variables

\begin{tabular}{|c|c|c|c|c|c|c|}
\hline & CR & FF & IH & SS & TA & IND \\
\hline CR & 1.000000 & & & & & \\
\hline FF & 0.124562 & 1.000000 & & & & \\
\hline IH & -0.024015 & 0.041019 & 1.000000 & & & \\
\hline SS & -0.122649 & -0.997764 & -0.040162 & 1.000000 & & \\
\hline TA & -0.086336 & -0.000743 & -0.001774 & 0.001527 & 1.000000 & \\
\hline IND & -0.070984 & 0.006855 & -0.054400 & -0.005810 & 0.145796 & 1.000000 \\
\hline
\end{tabular}

For the linear regression model (3) which used to test the third hypothesis,

$$
D E_{i t}=\alpha_{0}+b_{1} F F_{i t}+b_{2} I H_{i t}+b_{3} S S_{i t}+b_{4} T A_{i t}+b_{5} I N D_{i t}+e_{i t}
$$

Table (5) estimating the relation between (D/E), (FF), (IH) and (SS), it's found that there is a direct weak correlation between DE, FF, TA and IND while there is an inverse weak correlation between DE, IH, and SS.

Table (5) Correlation Matrix between Third Hypothesis Variables

\begin{tabular}{|c|c|c|c|c|c|c|}
\hline & D_E & FF & IH & SS & TA & IND \\
\hline D_E & 1.000000 & & & & & \\
\hline FF & 0.007735 & 1.000000 & & & & \\
\hline IH & -0.017995 & 0.041019 & 1.000000 & & & \\
\hline SS & -0.008226 & -0.997764 & -0.040162 & 1.000000 & & \\
\hline TA & 0.210340 & -0.000743 & -0.001774 & 0.001527 & 1.000000 & \\
\hline IND & 0.013240 & 0.006855 & -0.054400 & -0.005810 & 0.145796 & 1.000000 \\
\hline
\end{tabular}

For the linear regression model (4) which used to test the fourth hypothesis,

$$
D Y_{i t}=\alpha_{0}+b_{1} F F_{i t}+b_{2} I_{i t}+b_{3} S S_{i t}+b_{4} E P S_{i t}+b_{5} I N D_{i t}+e_{i t}
$$

Table (6) estimating the relation between (DY), (FF), (IH) and (SS), it's found that there is a direct weak correlation between DY, SS and EPS while there is an inverse weak correlation between DY, FF, IH and IND.

Table (6) Correlation Matrix between Fourth Hypothesis Variables

\begin{tabular}{|c|c|c|c|c|c|c|}
\hline & DY & FF & IH & SS & EPS & IND \\
\hline DY & 1.000000 & & & & & \\
\hline FF & -0.141853 & 1.000000 & & & & \\
\hline IH & -0.031515 & 0.041019 & 1.000000 & & & \\
\hline SS & 0.144808 & -0.997764 & -0.040162 & 1.000000 & & \\
\hline EPS & 0.226180 & -0.181669 & -0.018895 & 0.182523 & 1.000000 & \\
\hline IND & -0.063109 & 0.006855 & -0.054400 & -0.005810 & -0.123834 & 1.000000 \\
\hline
\end{tabular}

\subsection{The Linear Regression Models}

The regression models and the OLS method are based on several assumptions, including the constancy of homoscedasticity by which the mean should be 
equal to zero, and if the Heteroscedasticity variation is used, some methods are used to overcome this problem, such as the White test. The null hypothesis is that the model has a problem of random error instability if $p$-value is greater than 0.05 .

\section{For the First Hypothesis:}

White Stability test for random error variation is used to overall test of Hetroscedasticity, table (7) shows that P-value is less than (0.05) in for the independent variable, and the chi-square test of the model as a whole has a Pvalue of 0.04539 which means accepting the null hypothesis which means that the first model does not suffer from the problem of random errorinstability.

Table (7) First Hypothesis - Test of Hetroscedasticity

\begin{tabular}{|c|c|c|c|}
\hline \multirow{2}{*}{ Overall test of Hetroscedasticity } & Chi-square & Df & P - value \\
\cline { 2 - 4 } & 17.6556 & 19 & 0.045539 \\
\hline
\end{tabular}

Ramsey RESET test for model specification is used also to determine whether the model contains all the appropriate variables and excludes all irrelevant variables to ensure that the model estimated coefficients are not biased. This is done through the Ramsey RESET Test, and the decision criterion is to accept the null hypothesis that the study model includes all the appropriate variables $\mathrm{P}$-value was greater than (0.05). Table (8) shows $\mathrm{P}$-value for the $\mathrm{F}$ test is greater than $(0.05)$, which means that the first regression model does not contain any inappropriate Independent and dependent variables.

Table (8) First Hypothesis - Ramsey RESET Overall Test

\begin{tabular}{|c|c|c|c|}
\hline \multirow{2}{*}{ Ramsey RESET overall Test } & F-test & Df & P - value \\
\cline { 2 - 4 } & 2.537 & 2,633 & 0.0799 \\
\hline
\end{tabular}

Hausman test statistic is conducted in order to determine the appropriate panel model as follows:

$H=1.42184$ with $p$-value $=\operatorname{prob}($ chi - square $(4)>1.42184)=0.84039$

(A low p-value counts against the null hypothesis that the random effects model is consistent, in favor of the fixed effects model.)

Table (9) shows the best estimating model for panel regression relation is a Pooled panel regression model for the first hypothesis.

The best estimating equation for the first hypothesis is:

$R O E=-34.63+0.87 F F+1.012 I H+0.38 S S+2.14 E P S-6.43 I N D$

This equation is useful for short run as p-value of the independent and moderators variables coefficients less than 0.05 and long run forecasting as the 
value of R-squared $=0.013896<$ the Durbin Watson statistic of 0.338 , this means that residuals are in a stationary form.

Table (9) Results of the Pooled First Regression Model

\begin{tabular}{|c|c|c|c|c|c|c|}
\hline First Model & & $R O E_{i t}=\alpha_{0}+$ & $\begin{array}{l}\text { ooled Panel e } \\
b_{1} F F_{i t}+b_{2} I F\end{array}$ & $\begin{array}{l}\text { ect Regressio } \\
t+b_{3} S S_{i t}+b\end{array}$ & $\begin{array}{l}\text { model: } \\
P P S_{i t}+b_{5} I N D_{i t}\end{array}$ & \\
\hline Model variables & Constant & Indep.: FF & Indep.: IH & Indep.: SS & Moder.: EPS & Moder.: IND \\
\hline Variable Coefficient & -34.63 & 0.87 & 1.012 & 0.38 & 2.14 & -6.43 \\
\hline P-value at $\alpha=5 \%$ & 0.0325 & 0.0028 & 0.0001 & 0.0099 & 0.0463 & 0.0029 \\
\hline Significance & Significant & Significant & Significant & Significant & Significant & Significant \\
\hline $\begin{array}{l}R^{2} \\
\text { F-test statistic }\end{array}$ & \multicolumn{6}{|c|}{$\begin{array}{l}0.013896 \\
F(105,530)=4.80269 \text { with } p \text {-value } 8.29101034 \\
\text { (A low p-value counts against the null hypothesis that the pooled OLS model is adequate, ir } \\
\text { favor of the fixed effects alternative.) }\end{array}$} \\
\hline
\end{tabular}

For the Second Hypothesis:

White Stability test for random error variation is used to overall test of Hetroscedasticity, table $(1 \cdot)$ shows that P-value is less than (0.05) in for the independent variable, and the chi-square test of the model as a whole has a Pvalue of 0.008405 which means accepting the null hypothesis which means that the second model does not suffer from the problem of random errorinstability.

Table (10) Second Hypothesis - Test of Hetroscedasticity

\begin{tabular}{|c|c|c|c|}
\hline \multirow{2}{*}{ Overall test of Hetroscedasticity } & $\begin{array}{c}\text { Chi- } \\
\text { square }\end{array}$ & Df & P - value \\
\cline { 2 - 4 } & 33.99432 & 19 & 0.008405 \\
\hline
\end{tabular}

Table (11) shows P-value for the F test is greater than (0.05), which means that the second regression model does not contain any inappropriate Independent and dependent variables.

Table (11) Second Hypothesis - Ramsey RESET Overall Test

\begin{tabular}{|c|c|c|c|}
\hline \multirow{2}{*}{ Ramsey RESET overall Test } & F-test & Df & P - value \\
\cline { 2 - 4 } & 3.04147 & 2,635 & 0.0885 \\
\hline
\end{tabular}

Hausman test statistic is conducted in order to determine the appropriate panel model as follows:

$H=6.49737$ with $p$-value $=\operatorname{prob}($ chi-square $(4)>6.49737)=0.16495$

(A low p-value counts against the null hypothesis that the random effects model is consistent, in favor of the fixed effects model.) 
Table (12) shows the best estimating model for panel regression relation is a Pooled panel regression model for the second hypothesis.

The best estimating equation is for the second hypothesis is:

$C R=-4.93+0.089 F F-0.036 I H+0.068 S S-3.064 e-08 T A$

$$
-60.064 I N D
$$

This equation is useful for short run as p-value of the independent and moderators variables coefficients less than 0.05 and long run forecasting as the value of R-squared $=0.020670<$ the Durbin Watson statistic of 0.4325 , this means that residuals are in a stationary form.

Table (12) Results of the Pooled Second Regression Model

\begin{tabular}{|c|c|c|c|c|c|c|}
\hline \multirow{2}{*}{$\begin{array}{l}\text { Second Model } \\
\text { Model variables }\end{array}$} & \multicolumn{6}{|c|}{$\begin{array}{c}\text { Pooled Panel effect Regression model: } \\
C R_{i t}=a_{0}+b_{1} F F_{i t}+b_{2} I H_{i t}+b_{3} S S_{i t}+b_{4} T A_{i t}+b_{5} I_{N D_{i t}+e_{i t}}\end{array}$} \\
\hline & Constant & Indep.: FF & Indep.: IH & Indep.: SS & Moder.:TA & Moder.: IND \\
\hline Variable Coefficient & -4.93 & 0.089 & -0.036 & 0.068 & $-3.064 \mathrm{e}-08$ & -0.064 \\
\hline P-value at $\alpha=5 \%$ & 0.0164 & 0.0033 & 0.0002 & 0.0056 & 0.0231 & 0.0009 \\
\hline Significance & Significant & Significant & Significant & Significant & Significant & Significant \\
\hline $\begin{array}{l}R^{2} \\
\text { F-test statistic }\end{array}$ & \multicolumn{6}{|c|}{$\begin{array}{l}0.020670 \\
F(105,530)=6.539 \text { with } p-\text { value } 3.0015449 \\
\text { (A low p-value counts against the null hypothesis that the pooled OLS model is } \\
\text { adequate, in favor of the fixed effects alternative.) }\end{array}$} \\
\hline
\end{tabular}

\section{For the Third Hypothesis:}

White Stability test for random error variation is used to overall test of Hetroscedasticity, table (13) shows that P-value is less than (0.05) in for the independent variable, and the chi-square test of the model as a whole has a Pvalue of 0.0036691 which means accepting the null hypothesis which means that the third model does not suffer from the problem of random errorinstability.

Table (13) Third Hypothesis - Test of Hetroscedasticity

\begin{tabular}{|c|c|c|c|}
\hline \multirow{2}{*}{ Overall test of Hetroscedasticity } & Chi-square & Df & P - value \\
\cline { 2 - 5 } & 7.096430 & 19 & 0.0036691 \\
\hline
\end{tabular}

Table shows $\mathrm{P}$-value for the $\mathrm{F}$ test is greater than (0.05), which means that the third model does not contain any inappropriate Independent and dependent variables.

Table (14) Third Hypothesis - Ramsey RESET Overall Test

\begin{tabular}{|c|c|c|c|}
\hline \multirow{2}{*}{ Ramsey RESET overall Test } & F-test & Df & P - value \\
\cline { 2 - 5 } & 20.8745 & 2,633 & 1.66009 \\
\hline
\end{tabular}


Hausman test statistic is conducted in order to determine the appropriate panel model as follows:

$H=4.54317$ with $p-$ value $=\operatorname{prob}($ chi - square $(4)>$ $4.54317)=0.33746$

(A low p-value counts against the null hypothesis that the random effects model is consistent, in favor of the fixed effects model.)

Table (15) shows the best estimating model for panel regression relation is a Pooled panel regression model for the third hypothesis.

The best estimating equation is:

$D E=-0.80 F F-0.036 I H-2.92 e-06 T A+0.66 I N D$

This equation is useful for short run as p-value of the independent and moderators variables coefficients less than 0.05 and long run forecasting as the value of R-squared $=0.037550<$ the Durbin Watson statistic of 1.163637 , this means that residuals are in a stationary.

Table (15) Results of the Pooled Third Regression Model

\begin{tabular}{|l|c|c|c|c|c|c|}
\hline Third Model & \multicolumn{7}{|c|}{ Pooled Panel effect Regression model: } \\
\hline Model variables & Constant & Indep.: FF & Indep.: IH & Indep.: SS & Moder.: TA & Moder.: IND \\
\hline Variable Coefficient & 116.36 & -0.80 & -0.73 & -0.85 & $2.92 \mathrm{e}-06$ & 0.66 \\
\hline P-value at $\boldsymbol{\alpha}=\mathbf{5} \%$ & 0.1325 & 0.0028 & 0.0651 & 0.0599 & 0.001 & 0.0071 \\
\hline Significance & Insig. & Significant & Insig. & Insig. & Significant & Significant \\
\hline $\boldsymbol{R}^{\mathbf{2}}$ & $\begin{array}{l}\text { F-test statistic } \\
\text { F-037550 }\end{array}$ & $\begin{array}{l}\text { F(105, 530) }=2.33879 \text { with } p-\text { value } 3.3485010 \\
\text { (A low p-value counts against the null hypothesis that the pooled OLS model is adequate, } \\
\text { in favor of the fixed effects alternative.) }\end{array}$ \\
\hline
\end{tabular}

\section{For the Fourth Hypothesis:}

White Stability test for random error variation is used to overall test of Hetroscedasticity, table (16) shows that P-value is less than (0.05) in for the independent variable, and the chi-square test of the model as a whole has a Pvalue of 0.0285568 which means accepting the null hypothesis which means that the fourth model does not suffer from the problem of random errorinstability.

Table (16) Fourth Hypothesis - Test of Hetroscedasticity

\begin{tabular}{|c|c|c|c|}
\hline \multirow{2}{*}{ Overall test of Hetroscedasticity } & Chi-square & Df & P - value \\
\cline { 2 - 5 } & 13.19 & 19 & 0.028568 \\
\hline
\end{tabular}


Table (17) shows P-value for the F test is greater than (0.05), which means that the fourth model does not contain any inappropriate Independent and dependent variables.

Table (17) Fourth Hypothesis - Ramsey RESET Overall Test

\begin{tabular}{|c|c|c|c|}
\hline \multirow{2}{*}{ Ramsey RESET overall Test } & F-test & Df & P - value \\
\cline { 2 - 4 } & 2.537 & 2,633 & 0.0799 \\
\hline
\end{tabular}

Hausman test statistic is conducted in order to determine the appropriate panel model as follows:

$H=11.336$ with $p$-value $=\operatorname{prob}($ chi-square $(4)>11.336)=0.0230368$

(A low p-value counts against the null hypothesis that the random effects model is consistent, in favor of the fixed effects model.)

Therefore, best estimating model for panel regression relation is a Pooled panel regression model.

Table (18) shows the best estimating model for panel regression relation is a Pooled panel regression model for the fourth hypothesis.

The best estimating equation is:

$$
D Y=0.20 E P S-0.05 I N D
$$

This equation is useful for short run as p-value of the independent and moderators variables coefficients less than 0.05 and long run forecasting as the value of R-squared $=0.085442<$ the Durbin Watson statistic of 0.885 , this means that residuals are in a stationary form.

Table (18) Results of the Pooled Fourth Regression Model

\begin{tabular}{|c|c|c|c|c|c|c|}
\hline \multirow{2}{*}{$\begin{array}{l}\text { Fourth Model } \\
\text { Model variables }\end{array}$} & \multicolumn{6}{|c|}{$\begin{array}{l}\text { Pooled Panel effect Regression model: } \\
D Y_{i t}=a_{0}+b_{1} F F_{i t}+b_{2} I H_{i t}+b_{3} S S_{i t}+b_{4} E P S_{i t}+b_{5} I_{N D_{i t}}+e_{i t}\end{array}$} \\
\hline & Constant & Indep.: FF & Indep.: IH & Indep.: SS & Moder.: EPS & Moder.: IND \\
\hline Variable Coefficient & -11.0702 & 0.14 & -0.0418 & 0.17 & 0.20 & -0.05 \\
\hline P-value at $\alpha=5 \%$ & 0.4323 & 0.5095 & 0.4970 & 0.2303 & $<0.0001$ & $<0.0001$ \\
\hline Significance & Insig. & Insig. & Insig. & Insig. & Significant & Significant \\
\hline $\begin{array}{l}R^{2} \\
\text { F-test statistic }\end{array}$ & \multicolumn{6}{|c|}{$\begin{array}{l}0.058442 \\
F(105,530)=4.60617 \text { with } p \text {-value } 5.73927032 \\
\text { (A low p-value counts against the null hypothesis that the pooled OLS model is adequate, in } \\
\text { favor of the fixed effects alternative.) }\end{array}$} \\
\hline
\end{tabular}




\section{Conclusion}

This research adapted to test and examines the relationship between ownership structure (free float, institutional shareholding and managerial shareholding) on the financial performance, leverage and dividend policy of listed non financial companies in Egypt.

To test the research stated hypotheses, the ROE ratio, liquidity (Current ratio), financial leverage (debt/equity ratio) and dividend yield ratio are used as the dependent variables and the ownership structure types are used as the independent variables, in addation the earnings per share, total assets, industry type are used as the control variables.

All ratios have been computed over the six years horizon (2012-2017). The Statistical Package of Social Sciences (SPSS) tool was utilized to analyze the financial data by descriptive and inferential statistics (means, maximum, minimum and standard deviation) and (Pearson's correlation coefficients and simple linear regression) respectively. Ordinary Least Square (OLS) regression methods were used to model the relationship between the dependent variable and the independent variables.

The result shows a negative and statistically insignificant relationship between IH ownership and dividend yield and a postive and statistically insignificant relationship between FF ans SS and dividend yield.

The result shows an insignificant and negative relationship between leverage and ownsership structure. That means the firms with high ratio of ownership structure tend to have lower level of leverage and thus have increased opportunity to pay high level of dividends. In addation results indicates that large size firms are more able to obtain debts than smaller ones and have high EPS to pay dividends.

Based on our research, results can assist investors who consider the significant ownership structure of companies' ${ }^{6}$ on dividend yield, leverage and financial performance when deciding on investment in Egyptian stocks.

Thus, if investors' have an interest in high dividend from their investment, they should examine the ownership structure and the EPS of the company in evaluating their investment opportunities because some kinds ownership structures of firms tends to retain their dividends for reinvestment or depend more on leverage and debts.

Also, the results shows that the increase in agency problem between inside and outside shareholders, managers and debt-holders affected by ownership structure, their conflict in interests will either lead to improvement or damage of firms' financial performance and affect also the debt level in capital structure. A better financial accounting disclosure helps reducing these conflicts of interests between interested parties. 


\section{References}

1. Aghion and Tirole (2000). How Does Ownership Structure Affect Capital Structure And Firm Performance? Recent Evidence from East Asia. Journal of Management. 22, 3, 14.

2. Agrawal, A. and Knoeber, C.R. (1996). Firm Performance and Mechanisms to Control Agency Problems between Managers and Shareholders. Journal of Financial and Quantitative Analysis. 31, 377397.

3. Ajinkya B, Bhojraj S and Sengupta P (2005). The Association between Outside Directors, Institutional Investors, and the Properties of Management Earnings Forecasts. Journal of Accounting Research. 43, 343-375.

4. Ali, A. (2014). Ownership Structure and Voluntary Disclosure Level in Emerging Market: Evidence from Tunisia. Proceedings of the International Conference on Innovation \& Engineering Management, San Juan, USA. 130-140.

5. Amitava Roy (2015). Dividend Policy, Ownership Structure and Corporate Governance: An Empirical Analysis of Indian Firms. Indian Journal of Corporate Governance. 8, 1, 1-33.

6. Bostanci, F., Kilic, S. (2010). The Effects of Free Float Ratios on Market Performance: An Empirical Study on the Istanbul Stock Exchange. The ISE Review. 12, 45, 1-25.

7. Chau GK and Gray SJ (2010). Family ownership, board independence and voluntary disclosure: Evidence from Hong Kong. Journal of International Accounting, Auditing and Taxation. 19, 93-109.

8. Chiraz Ben Ali et al., (2007). Disclosure Quality and Ownership Structure: Evidence from the French Stock Market. European Accounting Association conference.

9. Cui, R. and Wu, Y. (2007). Disentangling Liquidity and Size Effects in Stock Returns: Evidence from China. Available from World Wide Web: http://ssrn.com/abstract $=910248$

10. Demsetz, H. and Villalonga, B. (2001). Ownership Structure and Corporate Performance. Journal of Corporate Finance. 7, 3, 209-233.

11. Emad Rezaei and Atefeh Tahernia (2013). The Relationship between The Percentages of Free Float Shares and Liquidity of Shares in the Companies Accepted in Tehran Stock Exchange. African Journal of Business Management. 7, 37, 3790-3798. 
12. Eric Gedajlovic and Daniel M. Shapiro (2002). Ownership Structure and Firm Profitability in Japan. Academy of Management Journal. 45, 2, 565-575.

13. Faruk Bostanci and Saim Kiliç (1997). The Effects of Free Float Ratios on Market Performance: An Empirical Study on the Istanbul Stock Exchange. The ISE Review. 12, 45, 1-25.

14. Gursoy, G. and Aydogan, K. (2002). Equity Ownership Structure, Risk Taking and Performance: An Empirical Investigation in Turkish Companies. Russian and East European Finance and Trade. 38, 5-24.

15. Hamid Ullah, et al. (2012). The Impact of Ownership Structure on Dividend Policy Evidence from Emerging Markets KSE-100 Index Pakistan. International Journal of Business and Social Science. 3, 9, 298307.

16. Hermalin, B.E. and Weissbach, M.S. (1991). The Effects of Board Composition and Direct Incentives on Firm Performance. Financial Management. 20, 4, 101-112.

17. Hichem Khlif et al., (2017). Ownership structure and voluntary disclosure: A synthesis of empirical studies. Australian Journal of Management. 42, 3, 376-403.

18. Holderness, C.G. (2003). A Survey of Block Holders and Corporate Control. Economic Policy Review. 9, 1, 51-64.

19. Hue T. M. Nguyen and Thao T. M. Giang (2015). Triangle Relationships among Ownership Structure, Dividend Policy and Firm Performance: An Empirical Study in Vietnamese Companies. Asian Social Science. 11, 27, 195-207.

20. Hui Zhang and Khine Kyaw (2017). Ownership Structure and Firm Performance: An Empirical Analysis of Chinese Companies. Applied Economics and Finance. 4, 2, 57-64.

21. Ifraz Khan, et al., (2013). The Impact of Ownership Structure on Voluntary Corporate Disclosure in Annual Reports: Evidence from FIJI. Accounting and Taxation. 5, 1, 47-58.

22. Jensen, M. and Meckling, W. (1976). Theory of the Firm: Managerial Behavior, Agency Costs, and Ownership Structure. Journal of Financial Economics. 3, 4, 305-360.

23. Kafash, Mohammad (2009). The Effect of Ownership Structure on Firm Performance in Tehran Stock Exchange. The Iranian Accounting and Auditing Review. 55, 51-67.

24. Khan, T. (2006). Company Dividends and Ownership Structure: Evidence from UK Panel Data. The Economic Journal. 116, 510, 172189.

25. King A. Salami (2011). Analysis of the Relationship between Share Ownership Structure, Corporate Governance Structure, and Corporate Investment Efficiency, using GSE Market Data (2005-9). Journal of Accounting and Finance. 11, 4, 111-118. 
26. Mahmoud Bani and Abolfazl Bani (2014). Study of the Relationship between the Percentages of Free Float Share With Respect To Financial Ratios. Journal of Business and Management Review. 3, 11, 221-226.

27. Mahmoud Mousavi Shiri et al., (2016). A Study of Impact of Ownership Structure and Disclosure Quality on Information Asymmetry in Iran. The Journal for Decision Makers. 41, 1, 51-60.

28. Maryam Salahinezhad and Kolthoum Mansouri (2013). The Effect of Ownership Structure on Corporate Liquidity Listed in Tehran Stock Exchange. Interdisciplinary Journal of Contemporary Research in Business. 5, 8, 372-388.

29. Masoyi Dadi Aliyu, et al., (2016). Ownership Structure and Payout Policy of Listed Deposit Money Banks in Nigeria. Journal of Accounting. 1, 87-101.

30. Morck, R., Shleifer, A. and Vishny, R.W. (1988). Management Ownership and Market Valuation. Journal of Financial Economics. 20, 293-315.

31. Muzammal Ilyas Sindhu, et al, (2016). Impact of Ownership Structure on Dividend Payout in Pakistani Non-Financial Sector. Cogent Business and Management. 3, 1, 1-11.

32. Namazi, M. Kermani, A. (2008). Effect of Ownership Structure on the Performance of Companies Listed on the Tehran Stock Exchange. Reviews for Accounting and Auditing. 53, 15, 83-100.

33. Omneya Abdelsalam et al. (2008). Board Composition, Ownership Structure and Dividend Policies in an Emerging Market Further Evidence from CASE 50. Managerial Finance. 34, 12, 953-964.

34. Ozer, B. and Yamak, S. (2001). The Role of Market Control on the Relation between Ownership and Performance: Evidence from Turkish Market. Available from World Wide Web: http://ssrn.com/abstract=268089

35. Seyed Jalal, et al., (2010). Ownership Structure of Iranian Evidence and Payout Ratio. Asian Social Science. 6, 7, 36-42.

36. Suleyman Karaca and Ibrahim Eksi (2012). The Relationship between Ownership Structure and Firm Performance: An Empirical Analysis over Istanbul Stock Exchange (ISE) Listed Companies. International Business Research. 5, 1, 172-181.

37. Syed Zulfiqar, et al., (2011). Impact of Ownership Structure on Dividend Policy of Firm (Evidence from Pakistan). International Conference on E-Business, Management and Economics. 3, 22-26.

38. Thanatawee, Y. (2013). Ownership Structure and Dividend Policy: Evidence from Thailand. International Journal of Economics and Finance. 5, 1, 121-132.

39. Thanatawee, Y. (2014). Ownership Structure and Dividend Policy: Evidence from China. International Journal of Economics and Finance. 6, 8, 197-204. 
40. Ullah H., Fida A. and Khan S. (2012). The Impact of Ownership Structure on Dividend Policy Evidence from Emerging Markets KSE100 Index Pakistan. International Journal of Business and Social Science. 3, 9, 298-307.

41. Uyar, A., Kilic, M., and Bayyurt, N. (2013). Association between Firm Characteristics and Corporate Voluntary Disclosure: Evidence from Turkish Listed Companies. Intangible Capital, 9, 4, 1080-1112.

42. Vroom, G., and Mccann, B. T. (2009). Ownership Structure, Profit Maximization, and Competitive Behavior. IESE Business School University of Navarra.

43. Xuanfeng Zhang and Fu Jia (2014). Does Ownership Structure Matter for Dividend Yield? Evidence from the Hong Kong Stock Exchange. Business and Economic Research. 4, 2, 204-221.

44. Yabei $\mathrm{Hu}$ and Shigemi Izumida (2008). The Relationship between Ownership and Performance: A Review of Theory and Evidence. International Business Research. 1, 4, 72-81.

45. Yurtoglu, B. (2000). Ownership, Control and Performance of Turkish Listed Firms. Emprica. 27, 2, 193-222.

46. Zeynep Önder (2003). METU Studies in Development, Ownership Concentration and Firm Performance: Evidence from Turkish Firms. 30, 181-203.

47. Zunaidah Sulong and Fauzias Mat Nor (2008). Dividends, Ownership Structure and Board Governance on Firm Value: Empirical Evidence from Malaysian Listed Firms. Malaysian Accounting Review. 7, 2, 5594.

\section{$\underline{\text { Appendix }}$}

\section{First Regression Model}

Apply Breusch-Pagan test to determine which is more significant Pooled or Random model is. (A low p-value counts against the null hypothesis that the pooled OLS model is adequate, in favor of the random effects alternative.)

$$
\begin{gathered}
L M=234.792 \text { with } p-\text { value }=\text { prob }(\text { chi }- \text { square }(1) \\
>234.792)=5.37544053
\end{gathered}
$$

Variance inflation factor test statistic of multi-collinearity:

Minimum possible value $=1.0$ while Values $>10.0$ may indicate a collinearity problem.

$\operatorname{VIF}(j)=1 /\left(1-R(j)^{\wedge} 2\right)$, where $\mathrm{R}(\mathrm{j})$ is the multiple correlation coefficient between variable $\mathrm{j}$ and the other independent variables.

Table (1) First Hypothesis - VIF Test

\begin{tabular}{|l|l|}
\hline Variable & VIF \\
\hline
\end{tabular}




\begin{tabular}{|l|l|}
\hline FF & 3.969 \\
\hline IH & 1.005 \\
\hline SS & 4.034 \\
\hline EPS & 1.051 \\
\hline IND & 1.019 \\
\hline
\end{tabular}

From the previous table it's concluded that all variables in the pooled linear panel model don't suffer from multi collinearity problem.

\section{First Model Forecasting}

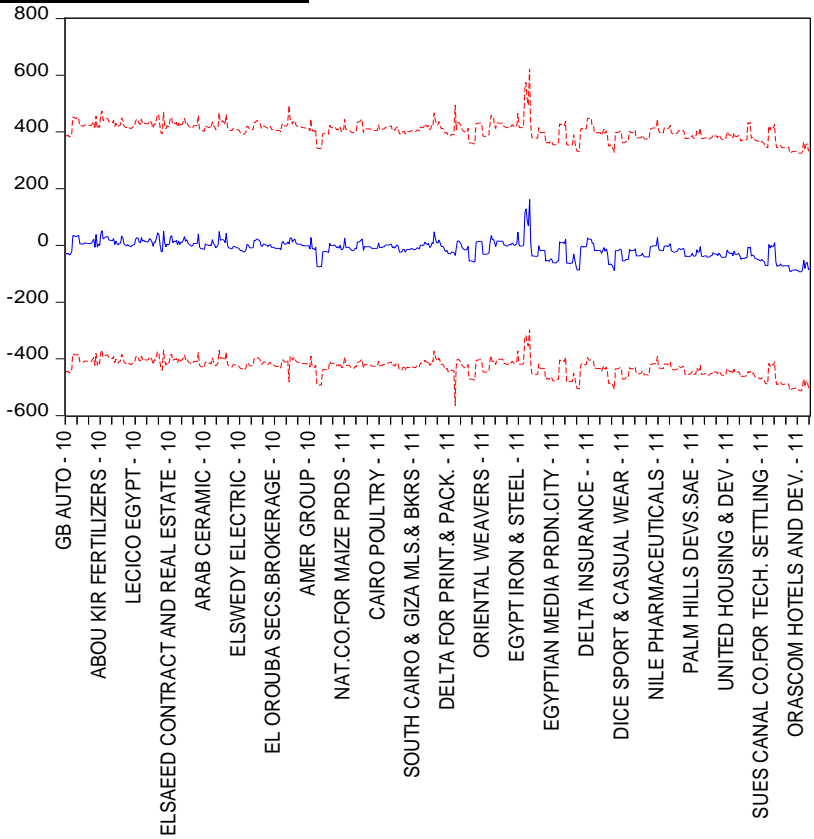

\begin{tabular}{|c|c|}
\hline Forecast: ROEF & \\
\hline Actual: ROE & \\
\hline Forecast sample: 201020 & \\
\hline Included observations: 641 & \\
\hline Root Mean Squared Error & 206.6440 \\
\hline Mean Absolute Error & 50.76262 \\
\hline Mean Abs. Percent Error & NA \\
\hline Theil Inequality Coefficient & 0.852758 \\
\hline Bias Proportion & 0.000000 \\
\hline Variance Proportion & 0.743726 \\
\hline Covariance Proportion & 0.256274 \\
\hline Theil U2 Coefficient & NA \\
\hline Symmetric MAPE & 156.0766 \\
\hline
\end{tabular}

Forecast sample: 20102015

NA

0.000000

0.743726

NA

56.0766

\section{Second Regression Model}

\section{Breusch-Pagan test statistic}

$$
\begin{gathered}
L M=351.23 \text { with } p-\text { value } \\
=\text { prob }(\text { chi }- \text { square }(1)>351.23) \\
=2.28701 e-078
\end{gathered}
$$

\section{Variance inflation factor test statistic of multi-collinearity:}

Minimum possible value $=1.0$ while Values $>10.0$ may indicate a collinearity problem.

$\operatorname{VIF}(j)=1 /\left(1-R(j)^{\wedge} 2\right)$, where $\mathrm{R}(\mathrm{j})$ is the multiple correlation coefficient between variable $\mathrm{j}$ and the other independent variables.

Table (2) Second Hypothesis - VIF Test

\begin{tabular}{|l|l|}
\hline Variable & VIF \\
\hline FF & 3.970 \\
\hline $\mathrm{IH}$ & 1.005 \\
\hline
\end{tabular}




\begin{tabular}{|l|l|}
\hline SS & 3.951 \\
\hline EPS & 1.022 \\
\hline IND & 1.025 \\
\hline
\end{tabular}

From the previous table it's concluded that all variables in the pooled linear panel model don't suffer from multi collinearity problem.

\section{Second Model Forecasting}

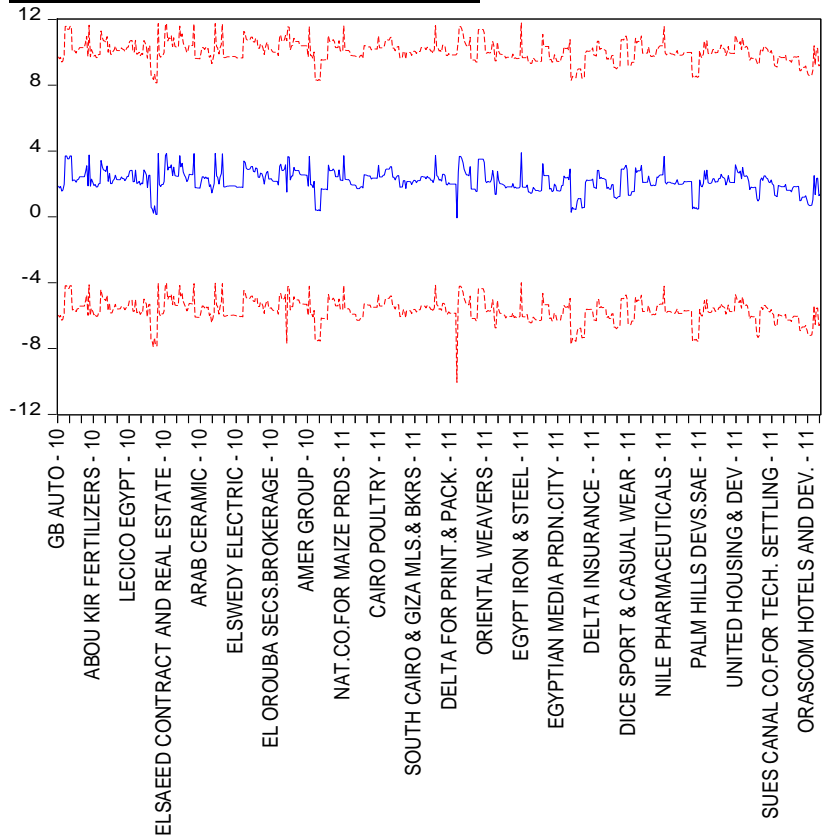

\begin{tabular}{|ll|}
\hline Forecast: CRF \\
Actual: CR \\
Forecast sample: 20102015 \\
Included observations: 641 \\
Root Mean Squared Error & 3.900873 \\
Mean Absolute Error & 1.589709 \\
Mean Abs. Percent Error & $\mathrm{NA}$ \\
Theil Inequality Coefficient & 0.575296 \\
$\quad$ Bias Proportion & 0.000000 \\
$\quad$ Variance Proportion & 0.711907 \\
$\quad$ Covariance Proportion & 0.288093 \\
Theil U2 Coefficient & $\mathrm{NA}$ \\
Symmetric MAPE & 70.17481 \\
\hline
\end{tabular}

\section{Third Regression Model}

\section{Breusch-Pagan test statistic}

$$
\begin{aligned}
L M=48.3487 \text { with } p-\text { value } \\
\quad=\operatorname{prob}(\text { chi }- \text { square }(1)>48.3487)=3.56783012
\end{aligned}
$$

\section{Variance inflation factor test statistic of multi-collinearity:}

Minimum possible value $=1.0$ while Values $>10.0$ may indicate a collinearity problem.

$\operatorname{VIF}(j)=1 /\left(1-R(j)^{\wedge} 2\right)$, where $\mathrm{R}(\mathrm{j})$ is the multiple correlation coefficient between variable $\mathrm{j}$ and the other independent variables.

Table (3) Third Hypothesis - VIF Test

\begin{tabular}{|l|l|}
\hline Variable & VIF \\
\hline FF & 3.970 \\
\hline IH & 1.005 \\
\hline
\end{tabular}




\begin{tabular}{|l|l|}
\hline SS & 3.951 \\
\hline EPS & 1.022 \\
\hline IND & 1.025 \\
\hline
\end{tabular}

From the previous table it's concluded that all variables in the pooled linear panel model don't suffer from multi collinearity problem.

\section{Third Model Forecasting}

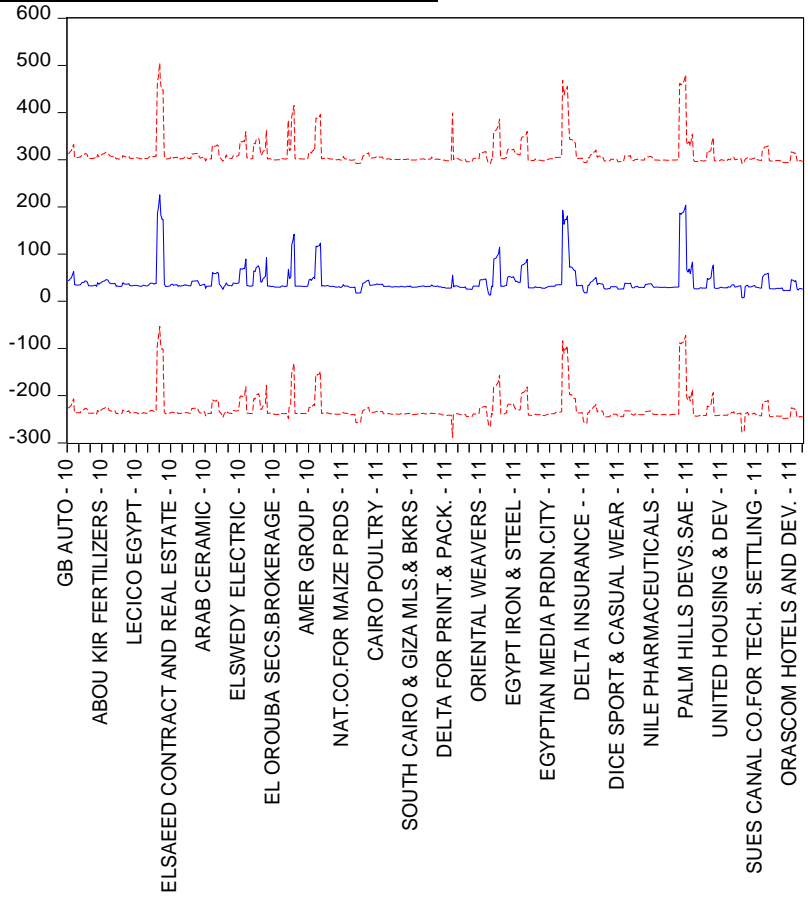

Forecast: D_EF

Actual: D E

Forecast sample: 20102015

Included observations: 641

Root Mean Squared Error $\quad 134.0262$

Mean Absolute Error $\quad 54.63801$

Mean Abs. Percent Error NA

Theil Inequality Coefficient $\quad 0.690638$

Bias Proportion $\quad 0.000000$

Variance Proportion $\quad 0.649763$

Covariance Proportion $\quad 0.350237$

Theil U2 Coefficient NA

Symmetric MAPE $\quad 121.6890$

\section{Fourth Regression Model}

\section{Breusch-Pagan test statistic}

$L M=202.499$ with $p-$ value $=\operatorname{prob}(\operatorname{chi}-\operatorname{square}(1)>202.499)$ $=5.95118046$

\section{Variance inflation factor test statistic of multi-collinearity:}

Minimum possible value $=1.0$ while Values $>10.0$ may indicate a collinearity problem.

$V I F(j)=1 /\left(1-R(j)^{\wedge} 2\right)$, where $\mathrm{R}(\mathrm{j})$ is the multiple correlation coefficient between variable $\mathrm{j}$ and the other independent variables.

Table (4) Fourth Hypothesis - VIF Test

\begin{tabular}{|l|l|}
\hline Variable & VIF \\
\hline FF & 3.969 \\
\hline $\mathrm{IH}$ & 1.005 \\
\hline $\mathrm{SS}$ & 4.034 \\
\hline
\end{tabular}




\begin{tabular}{|l|l|}
\hline EPS & 1.051 \\
\hline IND & 1.019 \\
\hline
\end{tabular}

From the previous table it's concluded that all variables in the pooled linear panel model don't suffer from multi collinearity problem.

\section{Fourth Model Forecasting}

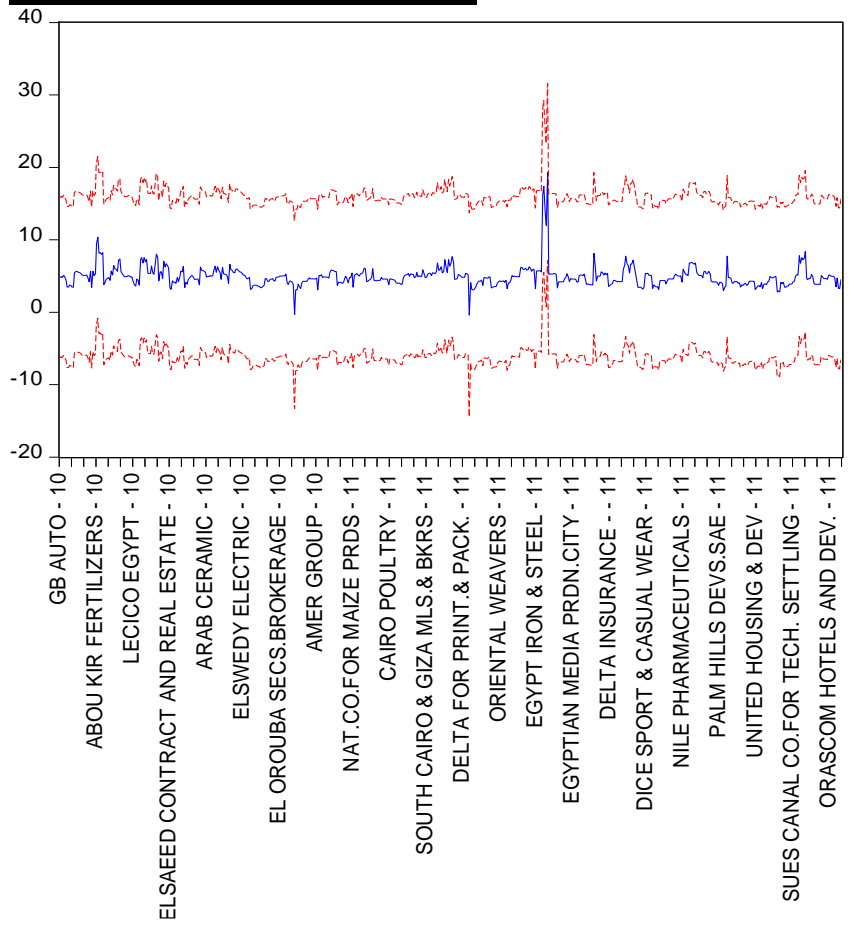

Forecast: DYF

Actual: DY

Forecast sample: 20102015

Included observations: 641

Root Mean Squared Error $\quad 5.4968 \varepsilon$

Mean Absolute Error $\quad 4.1856 \mathrm{C}$

Mean Abs. Percent Error NA

Theil Inequality Coefficient $0.4341 \mathrm{E}$

Bias Proportion $\quad 0.0000 \mathrm{C}$

Variance Proportion $\quad 0.59171$

Covariance Proportion $\quad 0.40825$

Theil U2 Coefficient NA

Symmetric MAPE $\quad 110.204$ 